\title{
SELECTED PROBLEMS OF IMPROVEMENT IN THE PROTECTION SYSTEM OF THE MOST IMPORTANT PEOPLE IN THE STATE
}

\author{
WYBRANE PROBLEMY DOSKONALENIA SYSTEMU \\ OCHRONY NAJWAŻNIEJSZYCH OSÓB W PAŃSTWIE
}

\author{
Dawid ZAJKO \\ Piotr ZASKÓRSKI
}

Military University of Technology

\begin{abstract}
The article focuses on the system of protection for the State's very important officials and objects in Poland. As in every country, there are specialized units designated for protective tasks of such people and objects. At the time of the revival of the Polish State after 123 years of outside dependence, the most essential national institutions were created, as it became indispensable to establish cells and services competent to protect its officials and objects in the State. The protection system is subject to constant evolution and successive modification. The protection model should evolve, and be adapt to new potential threats. This includes the process of transformation because of the use of modern tools and technologies. People in high positions and State officials may be at high risk of attacks on their life and health. Such persons require effective protection at an appropriate level, taking into account the available potential and its effective use. In order to guarantee effective protection of VIPs, it is necessary to properly organize this service, what is determined by State's institutional structures, tools and appropriate management techniques.

Abstrakt. Artykuł dotyczy problematyki systemu ochrony najważniejszych osób i obiektów w Polsce. Jednostki wydzielone do zadań ochronnych mają kluczowe znaczenie dla bezpieczeństwa najważniejszych osób w Rzeczpospolitej Polskiej, jak i w innych krajach Europy orazświata. W momencie odrodzenia się po 123 latach państwa polskiego, kiedy formowano i obsadzano najważniejsze urzędy, nieodzowne stało się powołanie komórek i służb właściwych do systemu ochrony najważniejszych osób i obiektów w państwie. System ochrony podlega ciagłej ewolucji i sukcesywnej modyfikacji. Model ochrony powinien być dostosowany do nowych potencjalnych zagrożeń $i$ w adekwatny sposób podlegać procesowi transformacji przez wykorzystanie nowoczesnych narzędzi i technologii. Osoby zajmujace wysokie pozycje w państwie moga być bardzo narażone na ryzyko zamachów na życie i zdrowie, dlatego wymagają skutecznej ochrony na odpowiednim poziomie z uwzględnieniem dostępnego potencjału i jego efektywnego wykorzystania. $W$ celu zagwarantowania efektywnej ochrony VIP-ów niezbędna jest właściwa organizacja tej służby, która determinowana jest strukturami, narzędziami oraz właściwymi technikami zarządzania.
\end{abstract}

Keywords: protection system, protection model, VIP protection, risk, security

Słowa kluczowe: system ochrony, model ochrony, ochrona VIP, ryzyko, bezpieczeństwo 


\section{Introduction}

The purpose of this article is analysis the system of ensuring the safety to the most important people in the state. At this stage, it is important to ask the question: what kind of factors decide about insufficient safety level of the most important people and objects in the state? Such question may divided into following detailed questions about:

- $\quad$ organization of system ensuring security to the most important people and objects in the state;

- $\quad$ effectiveness of the above system;

- determinants of the protection system of the most important people and objects in the state;

- analysis and assessment - in a longer time perspective - of previous incidents in the protection system of the most important people and objects in the state.

Therefore, for further consideration, we can hypothesize that protection of VIPs safety level, is determined by consistency of structures, operating procedures, resources as well as the budget, with special regard to effectiveness of using the available potential.

\section{Scope of the problem}

According to T. Kotarbiński the organization is: "a certain kind of a wholeness due to relation to it its own elements, namely such a wholeness, whose all its elements contribute together to the success of wholeness" (Kotarbiński 1985, p. 68). Therefore, the organization could be understood inter alia in the meaning of (Zieleniewski 1978, p. 50):

- result of action (obtained result as undertaking a conscious internal process in the organization), in the attribute aspect, as the level of obtaining the appropriate features of the action, as well as within the meaning of the entities and resource (potential and resources of state offices, services and institutions as well as enterprises and other entities);

- functioning and process, including operating procedures and factors affecting on the efficiency of the performed activities (the process becomes an organizational object).

In tasks related to the reaction on given threats, all efficient component resources of organization are crucial, and each of the factors have its indispensable participation to the final result, which is the security of the examined organization (Zaskórski 2011, p. 12). Max Weber was the first who identified the definition of a formal organization as a "acting deliberately, rationally organized structure, provided with some separate, internal social order" (Gabara 1989, pp. 124, 127). Therefore, each organization should be identified in holistic/systemic meaning, which mean that organization (Morgan 1997, pp. 322-333) acts in internal and external conditions for achieving intended purpose. System analysis is a perspective showing the world 
in the category of layouts and relations which are internal and external integrated. Systemic aspect presents a modern approach in the study of society, nature and any entities of activities. This is a comprehensive way of organizing and assessment of the obtained research results (Zaskórski 2011, p. 13). In the system analysis, we can extract four stages (Piekarczyk, Zimniewicz 2010, pp. 44-45):

- purpose analysis,

- division and analysis of the components,

- analysis of the relationships as well as external and internal relations,

- $\quad$ analysis of system behavior (response to certain stimuli).

System analysis of the organization need to emphasized the identification and division of the system components, external and internal relations between elements in a designated area and time of operation, including connections with other systems and entire surroundings influencing on the result of the action, as well as strength and dynamics of couplings inside the system (synergy of action) and feedbacks (Zaskórski 2011, p. 13).

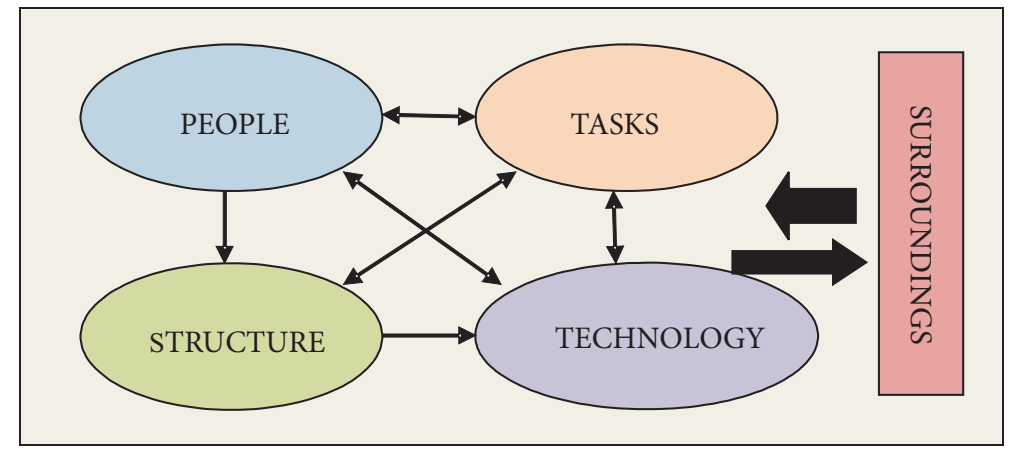

Fig. 1. Organization model according to H.J. Leavitt

Source: Own study based on (Zaskórski 2011, p. 13)

It is worth to consider the organization as a model system of action (Fig. 1), which means that "the organization is internally integrated with the wholeness", which consists of four key subsystems (subsystems elements (Długosz 1990, p. 44)), including the subsystem of:

- $\quad$ tasks and goals, which are achieved by organization;

- performers as performer teams (in the VIP protection system: officers and civil employees as well as teams of individual and collective aspirations and behavioral patterns);

- technical and material resources (equipment) and its using principle;

- formal structure, principles of division of the tasks, as well as responsibility for results of actions, as well as established competencies related to responsibility and access to the current information. 
Each organization - and therefore the VIP Protection System (SOVIP) - in a systemic aspect is associated with various interactions with the surroundings. We treat organization as an open-system which takes input elements from the surroundings, and consequently transforms them into output elements (maintaining the system's continuity operation). Recognizing the services responsible for the security of the most important people in the state (SOVIP) as an open-system, may indicate many positive factors, but also new threats. Manner of disposition of available resources may be determined by external conditions. The measure of usage level of the available potential is usually the effectiveness, which can be defined in various manner depending on category of investigated problem (Zaskórski et al. 2015, p. 255). The systemic aspect of effectiveness indicates the level of realization of the set goals in connection with the mission and strategy of the given organization. It should be assumed that above is a highly objective but also an unusual systemic criterion, due to the fact that effectiveness reflects the state of the entire system and its components as well as particular processes (Zaskórski et al. 2015, p. 255). Therefore, effectiveness is a factor which shows cost of the achieving goal/goals for a given system (company, office or institution (Zaskórski et al. 2015, p. 255)) and in systemic aspect is expressed as a quotient of purpose and expenditures:

$$
E f=\frac{E}{N},
$$

where: $E f$ - means effectiveness;

$E$ - means effect, result of the action (value of the goal);

$N$ - means material and financial expenditures (costs).

It should be noted, that the analysis of the effectiveness value is related with the analysis of objective and subjective factors inter alia with experience of the manager (or chief) of the task team, his knowledge, individual goals, as well as with the operating environment. The various processes realized in the area of a given undertaking, usually require a different interpretation of the effectiveness value. Therefore, results of the partial goals value and type of particular cost influence on SOVIP assessment (Zaskórski et al. 2015, p. 256) inter alia in the context of used resources and the level of achieved goals.

Classification of the effectiveness types was presented on Fig. 2. The effectiveness analysis favors an objective analysis of needs, especially in relation to the possibility of incurring certain costs. This is related to the need of detailing the reliability of information-decision processes and the level of corrective and improvement activities, taking into account the effectiveness criterion for the realized processes (Zaskórski et al. 2015, p. 258). Therefore, SOVIP is a set of elements (parts) connected with each other by relations (dependence) creating the wholeness which is qualitative 
different, from simple summary of individuals components (Ficoń 2007, p. 24). Above means, that system has a specific structure and creates some functional wholeness, taking into account the effectiveness, which is determined by synergy (Zaskórski et al. 2015, p. 55) through reinforcement of value resulting from:

- having a specific wholeness and a multi-level, complex structure;

- operating according to unified procedures and concrete criteria mainly profiled by guaranteeing security of system (stabilization) in the context of effectiveness and reliability of operations.

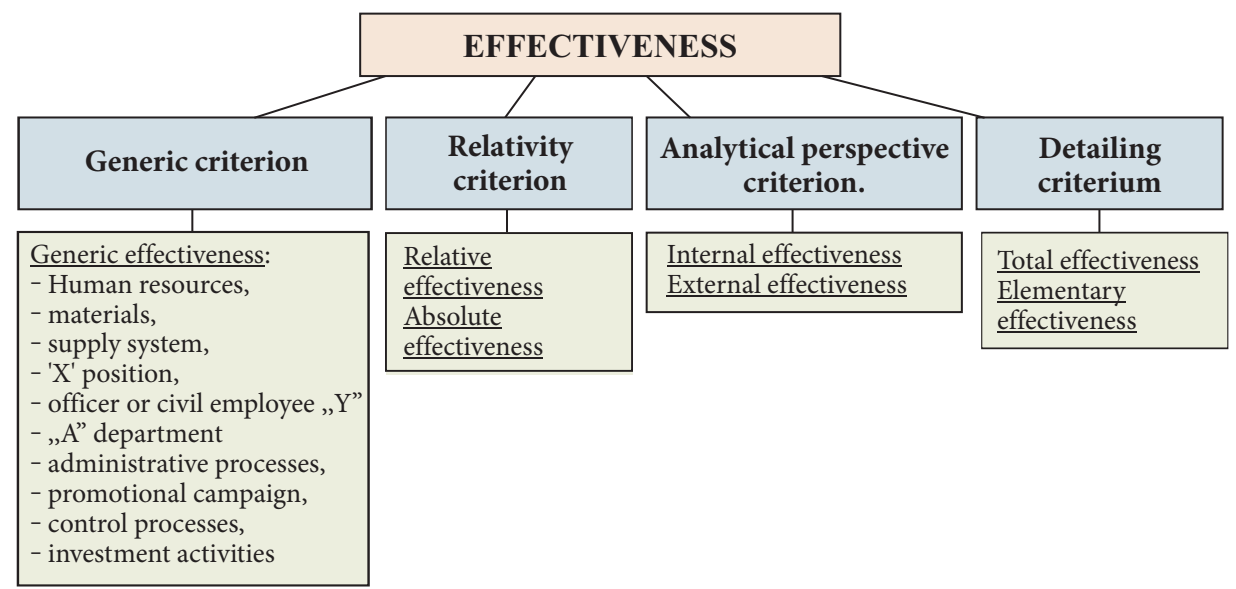

Fig. 2. Classification of the effectiveness types

Source: Own study based on (Zaskórski et al. 2015, p. 257)

Generally, the system is distinguished by desirable attributes, which reflects their specificity, including (Zaskórski et al. 2015, p. 58):

a) Coherent wholeness, which is consisted of interdependent elements and relations.

b) Striving for achieving of specific goals, by realization of system functions (praxeological system).

c) Communication and interaction channels (maintaining relations with the surroundings).

d) Realization the transformation processes of input elements (needs) into output elements (possibilities) with the necessity of processing the adequate information, regarding every process and consumed resources. Following to the final, expected state of relative balance and stabilization by pursuing the chosen goals within given missions.

e) In the identification and evaluation of each system, including - and perhaps above all - SOVIP we should focus on the output elements (view of needs) and 
on the input elements (view of possibilities). Available possibilities (potential) of the system are (Zaskórski et al. 2015, p. 58) therefore visible through:

- resources (tangible possibilities, materials, tools - and technical and technological resources);

- budget (possibilities in the meaning of capital identified in SOVIP primarily with capital not only financial, but also human one, including the knowledge of officers and employees as well as tools supporting decision-making processes);

- technology as well as knowledge about taking processes;

- infrastructure (is a subsystem of objects and elements which enable realization of transformation processes including ICT infrastructure, logistics infrastructure, technical and communication infrastructure as well as social infrastructure etc.);

- information and more general: access to information resources (as one of the main elements of both the input and output of a given system, which is the basis for effective and efficient management). Data and information determine the system and its surroundings, giving the opportunity to adopt to surroundings changes.

The actual value of each system, including the SOVIP system depends on the obtained results, which describes its output (Zaskórski et al. 2015, p. 58), i.e.:

- products and services as well as results of intellectual processes (operation projects, concepts);

- $\quad$ adverse effects (deficiencies, operational mistakes, waste and pollution).

It is worth noting, that in every activity, informations are obtained as a result of new experiences after the realization of the next process/task, which favors determination of not only weaknesses and mistakes, but also strong points.

\section{SWOT elements of the protection system of the most important people and objects in the state}

The protection system model in individual countries is different. Protection models e.g. European, are differ from Americans or Asians models. An example of the most known protection service is the American Secret Service, which is mainly responsible for the security and protection of US Presidents and their families, other high level officials and official guests in the US. American Secret Service has existed since 1865 , its annual budget fluctuates within 2.800 .000 dollars $(1,49 \%$ of the US PKB in 2016) and its employed around 5 thousand agents (https://www.secretservice. gov/protection/\#who). For comparison, in formation responsible for VIPs safety, the number of officers is unknown since this kind of information is undisclosed. Based on internet articles and Ministry of the Interior and Administrative data we 
can only specify a range of approx. 2-2.5 thousand officers (which eventually will increase up to 3 thousand officers). The Polish budget designed for VIP protection fluctuates around $0.05 \%$ of GDP $\left(2016^{1}\right)$. From the initial analysis, we can notice that Polish budget for the protection of the most important people in the state is inadequate. In addition, the weakness of this system is too many officers work in administration, towards not enough officers work in the field. A certain assumption and requirement for our solutions should be the fact, that American Secret Service, beside carrying out the protective tasks of the most important people in the US and the delegation, also deals with the prevention of corruption, financial fraud, identity theft and computer crime.

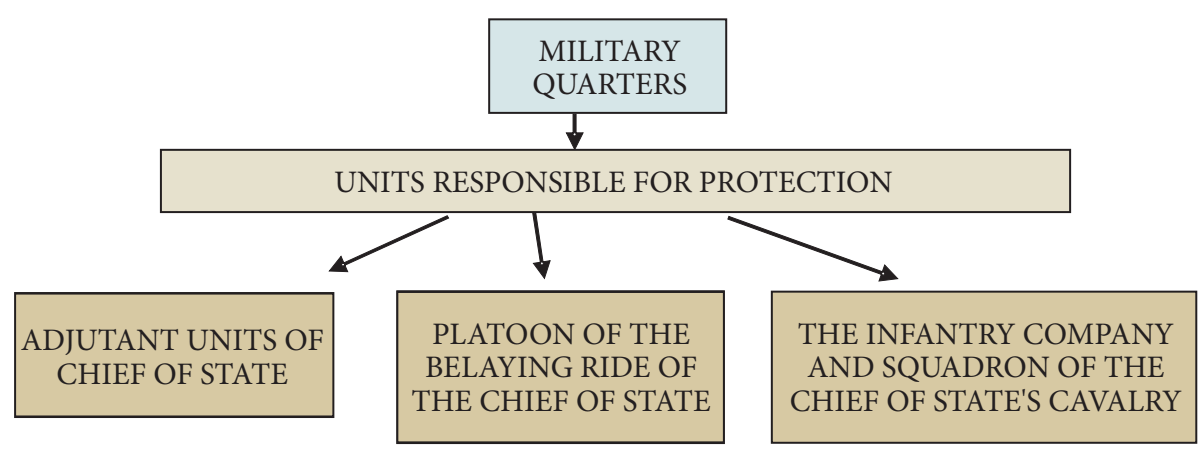

Fig. 3. The structure of units responsible for protection in 1919

Source: (Gnat-Wieteska 1992, p. 7)

Units for protective tasks had and have the key meaning for the security of the most important people and objects in the Polish state as well as in other European and World countries. In the moment of rebirth of the Polish Country after 123 years, when the most important offices were formed and positions were entrusted, the creation of units and appropriate services to the protection system of the most important persons and objects in the state, became indispensable. A series of spectacular attacks on the heads of states in the period before the First World War (including the assassination of Archduke Franz Ferdinand in Sarajevo in June 28, 1914), convinced everyone, that the creation of this type of service is an indispensable necessity. In addition, in Poland there was the problem of unregulated borders of the newly-reborn Polish state, also conflicts with neighboring countries and the Bolshevik revolution in Russia. From historical analysis of that period results many current requirements for contemporary solutions. For example, entrusting military and civil authority to Marshal Józef Piłsudski, caused the necessity of establishing permanent

1 The Ministry of Internal Affairs and Administration - https://mswia.gov.pl/pl/aktualnosci/ 16932,Sluzba-Ochrony-Panstwa-zastapila-BOR.pdf (access: 19.04.2018). 
components of the VIP's security system, including a military and a civil law office as well as units responsible for the protection of the Chief of State. In addition, the period between 1918 and 1919 can be described as the beginning of the initiation of the Polish VIP's Protection System (PSOVIP) (Czerniawski 1975, p. 164). The structure of units responsible for protection in 1919 was presented on Fig. 3.

The basic problem in area of protection, is relation with the protected person, who for example does not consent for such protection, or does not consent to secured in any way its functioning in various situations that give rise the risk of losing personal security. An important factor causing reluctance to protection is doubts that any protection could counteract the effectively emerging risk, including counteracting groups capable of carrying out an attack on life (Lepecki 1987, pp. 85-93). The negative attitude to the direct protection and protection of most important objects does not conducive to the efficiency and effectiveness of the officers operations in performing their tasks in each system of protection of the most important people in the state (Lepecki 1987, pp. 85-93). The examples of such difficult VIP' was Marshal Józef Piłsudski, who was suspicious and unwilling to cooperate with personal protection, which consisted of constant direct "physical" monitoring of the Chief of State. His assessments of SOVIP activities was often related to the statement that protection service is more concerned with watching him than with its actual protection. Above means, that each VIP has its own unique experience. Even working out the arrangements regarding protection and its activities could be problematic. Most of action in this direction could have heightened the level of distrust. ${ }^{2}$ SOVIP should be characterized by professionalism not only in its activities, but also in preparation. In connection with the above, the organization of security services at that time was necessary. Immediately after establishment of such services, it was found that the operation of protection system must be almost imperceptible to the protected person (the Head of State (Lepecki 1987, pp. 85-93).

An important attribute of SOVIP is adaptation (adaptation of operating procedures) in a situation where the VIP stays at the workplace or residence as well as, when he leaves the city, or leaves the territory of Warsaw or Poland (Lepecki 1987, pp. 85-93). According to the above, on the protection system regarding the protection instructions, the protected person should not have any influence. All issues related to security should be consulted with the Chief of Security, at the same time VIP should follow the safety rules according to the adopted procedures which guarantee effective protection. Because of that, SOVIP should be an open system, flexible to situational changes depending on the operating conditions, including for example: passage of cars column (Litwiński 2005, p. 13), travel by plane, stay at workplace, in the place of residence, in the place of temporary stay (meetings), and during the

2 Adjutant - oficer of the VIP's protective group. 
VIP's walk from point $X$ to point $Y$ (the model organization/arrangement of units (services) during the VIP's driving the car was presented on Fig. 4).

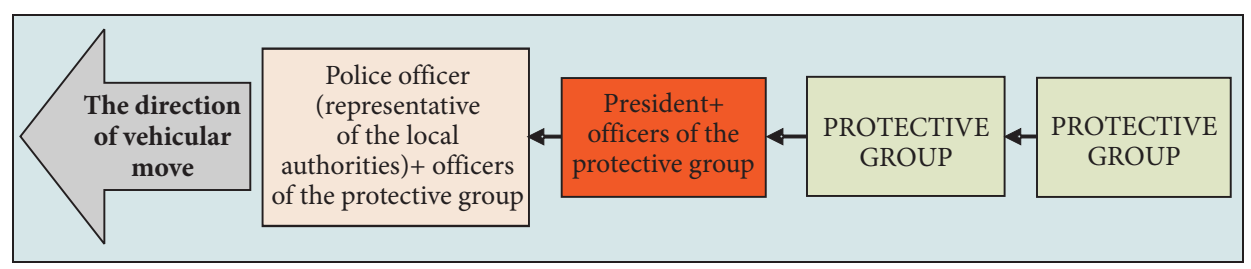

Fig. 4. Passage of the President cars column

Source: Own study based on (Litwiński 2005, p. 13)

Based on the experience and analysis of various situations, is also assumed that SOVIP in the place of residence or work of the protected person, should be organized in the so-called protective ring (safety cordon) in configuration, as in Figure 5, where $(\mathrm{P})$ means protected person:

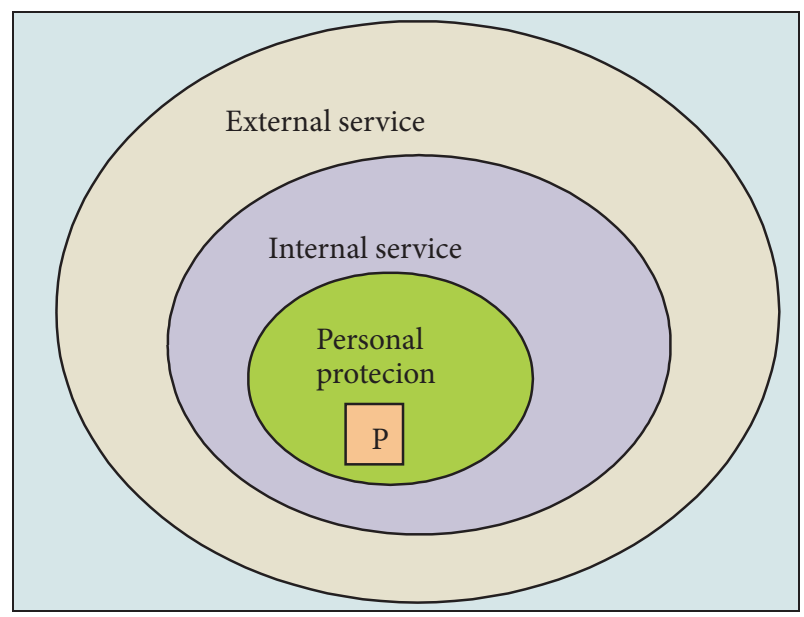

Fig. 5. Cordon (ring) of the President's safety in place of living or workplace Source: Own study based on (Litwiński 2005, p. 13)

One of the important observations resulting from SWOT analysis of existing SOVIP in different countries is keeping up with changes, but also standardizing operating procedures. The VIP protection system consists of a number of different elements which are subject to successive changes and must actively adapt to the emerging new threats. Therefore, an important assumption for new effective concepts and efficient concepts of SOVIP improvement is the successive implementation of modern technical and technological solutions as well as new management tools and techniques. 


\section{The concept of improving the VIP protection system}

Above-mentioned results of the general SWOT analysis indicates that protection system of the most important people (Fig. 6) and objects in the state, in the systemic aspects should dynamically adjust the needs to the possibility of acting, according to the criterion of protection and ensuring security as "protection against something bad, adverse or dangerous" (https://sjp.pwn.pl/sjp/ochrona;2492479.html). Another requirement may be to create a such SOVIP, which effectively implements protection process against something that is a threat (https://sjp.pwn.pl/sjp/ochrona;2492479. $\mathrm{html})$. In the case of protection of the most important people in the state, the authorized executor becomes a "person or group of people (a protective group) watching over someone's security” (https://sjp.pwn.pl/sjp/ochrona;2492479.html).

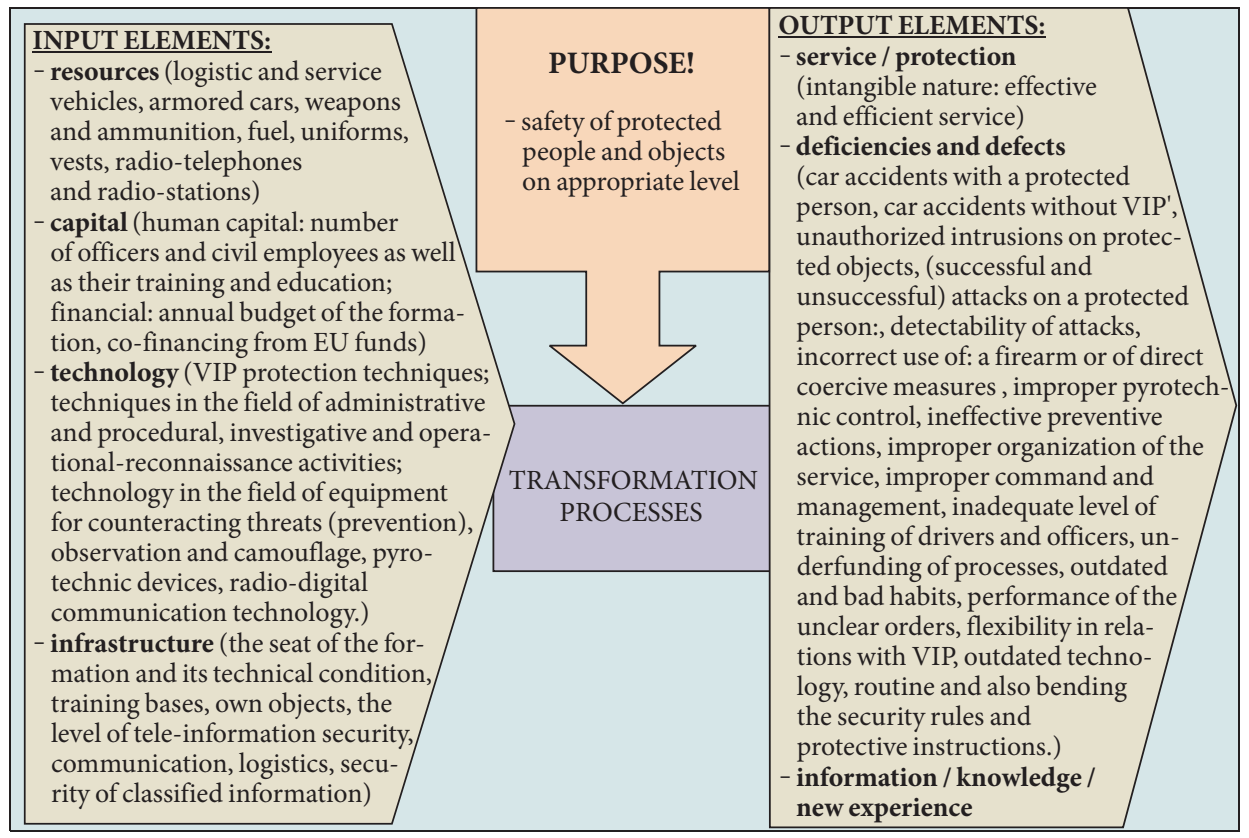

Fig. 6. Framework model of the protection system of the most important people in the state Source: Own study based on (Zaskórski et al. 2013, p. 55)

Personal protection is a derivative of protection, which mainly concerns providing security to VIPs (Presidents, Prime Ministers) and the main purpose of personal protection is to protect the life and health of the above VIPs. Protection of the most important state people, must be well-trained, highly experienced and well-motivated. First of all, such VIPs protection should counteract and thwart attacks on protected people, analyze potential threats and also should carry out 
simulations of threats according to various scenarios, to eliminate the possibility of a threat to protected person. Physical and psychological fitness, the ability to learn extreme driving, medical training, excellent knowledge of the weapons use, resistance to stress, availability, discretion are main features, and at the same time the basic features of an SOVIP officer.

An analysis of past experience indicates that there are quite significant deficiencies in this area. The accidents of important personalities in Poland recently contributed to the liquidation of the Government Protection Bureau (hereinafter: "BOR") in 2018 and the establishment of the State Protection Service (hereinafter: "SPP") in its place. It remains an open question, whether such decision was justified, and the significant expenses related to it will improve the protection system of the most important people in the state? The current observation allows us to state that, at the beginning the activities of the new formation (SPP), the accident rate did not diminish, and experienced officers were taken over by other formations (payment of quite high housing equivalents) or their professional activity ceased (retirement). Not the best situation of the SPP does not result from poor training of officers, but rather from poor organization, lack of financing or errors in training. Therefore, liquidation of BOR is debatable, since maybe it was necessary to analyzed and remove the defects identified at the SOVIP output, which had unfixable character, and at the same time the lacks should be submit to the reproducible process. In accordance with the principle of effectiveness (expressed as quotient of a goal and costs), it would be more profitable to repair/improve the BOR system, than complete transformation to the form of SPP - since initial analyzes indicates that the sum of costs may be greater than the expected goal. Based on the official data, liquidation of BOR may cost the state budget a minimum of 400.000 .000 million zlotys (https://www.wprost.pl/polityka/10108240/ile-kosztowala-likwidacja-borsetki-milionow-zlotych-dla-bylych-funkcjonariuszy.html) (2,000 former officers. In addition 250 officers are waiting for the payment of a housing equivalent i.e. approx. 75.000.000 zlotys). Above amount does not include charges for exchange of license plates, evidence, documents, uniforms, ID cards, change of the formation and name logos, changes of websites, etc. It can be assumed that if above amounts would have been introduced to improve existing protection system, it would give more effective solutions. Should be carried out a reform of formation only by statutory granting of additional powers, instead of liquidation. Defects and deficiencies in the output system could be removed or reduced their negative effects, including through:

- financing of training and raising the annual budget of the formation;

- introducing specialized courses for the managerial staff;

- introducing specialized training in extreme driving education for officers and increasing the number of shooting hours;

- giving additional investigation's and operational-reconnaissance powers regarding protection of the most important people; 
- limiting the flexibility vis-a-vis protected people (standardization of modern procedures);

- equipping with modern firearms and better means of transport (including armored cars);

- reducing the administration inside the service and increasing the number of the field officers;

- improving radio and digital communication and renovation of the training base and own objects (seat of the formation);

- sealing the security system of classified information, reorganizing the structure inside the formation, increasing responsibility for not following the protective instructions. ${ }^{3}$

The idea based on the repair and improvement of the existing system could therefore, have its justification, mainly in the aspect of maintenance of personal and informative continuity of activities. Therefore, the assumption about increasing salaries of officers and eliminating other components (e.g. housing equivalents) could be a quite important motivating factor of effective transformations in the existing structure.

\section{Implementation recommendations and conclusions}

The adopted in research and analyzes hypothesis that safety level is determined by consistency of structures, operating procedures and the effectiveness of the entire system, seems to be positively verified. Results of above research confirms that contemporary models of organizational structures and effectiveness are crucial for SOVIP, and also have influence to ensure the safety of the protected people. The systemic aspects of the protection processes of the most important people in the state indicates a strong link between the expenditures and effects of the action. The implementation of the systemic solutions enables limiting inefficient actions and to effective counteracting of:

- budget constraint for formation responsible for VIP's protection;

- losses resulting from lowering the profitability of global changes in the face of ability to repair/improve existing tested solutions, since the sum of expenditures is greater than the expected goal;

- improper command and management process (outdated and bad work habits and unclearness of tasks and competences);

- inappropriate relations with VIP, routine and non-compliance with the safety rules and protective instructions;

- insufficient level of training of drivers/officers (or lack of training) in the field of the extreme driving education.

3 Based on own experience and expert interview with BOR/SOP officers. 
Systemic aspect of protection of the most important people in the state shows, that such system should be improved and constantly subjected to effective modifications. Moreover, SOVIP should be transformed and also should improve its protection against new potential threats and improve its technology to be effective. Therefore, the system may be improved by statutory changes and the granting of additional rights, including through changes in the structure and organization as well as modernization of solutions in the area of management and implementation of new material and ICT technologies.

\section{BIBLIOGRAPHY}

[1] Czerniawski, E.J., 1975. Z mojej służby w Belwederze. Zeszyty Historyczne nr 33. Paryż.

[2] DŁugosz, M., 1990. Gry decyzyjne w badaniach i doskonaleniu organizacji. Warszawa.

[3] Ficoń, K., 2007. Inżynieria zarządzania kryzysowego. Podejście systemowe. Warszawa.

[4] Gabara, W., 1989. Nauka o organizacji i zarządzaniu. Warszawa.

[5] Gazeta Wprost, https://www.wprost.pl/polityka/10108240/ile-kosztowala-likwidacja-bor-setkimilionow-zlotych-dla-bylych-funkcjonariuszy.html [access: 19.04.2018].

[6] Gnat-Wieteska, Z., 1992. Szwadrony Przyboczne i Szwadron Reprezentacyjny Wojska Polskiego w latach 1919-1948. Pruszków.

[7] Kotarbiński, T., 1985. Traktat o dobrej robocie. Wrocław.

[8] Lepecki, M., 1987. Pamiętnik adiutanta Marszałka Piłsudskiego. Warszawa.

[9] Litwiński, R., 2005. Ochrona dostojników państwowych przez policję w II Rzeczpospolitej. Niepodległość. Czasopismo Poświęcone Najnowszym Dziejom Polski. tom LV, s. 11-35.

[10] Morgan, G., 1997. Obrazy organizacji, Warszawa.

[11] Piekarczyk, A., Zimniewicz, K., 2010. Myślenie sieciowe w teorii i praktyce, Warszawa.

[12] Serwis ABC Ekonomii, http://www.abc-ekonomii.net.pl/s/efektywnosc.html [access: 19.04.2018].

[13] Słownik języka polskiego PWN, https://sjp.pwn.pl/szukaj/cybernetyka.html [access: 19.04.2018].

[14] Słownik języka polskiego PWN, https://sjp.pwn.pl/szukaj/system.html [access: 19.04.2018].

[15] Słownik języka polskiego PWN, https://sjp.pwn.pl/sjp/ochrona;2492479.html [access: 18.04.2018].

[16] Strona Ministerstwa Spraw Wewnętrznych i Administracji, https://mswia.gov.pl/pl/aktualnosci/ 16932,Sluzba-Ochrony-Panstwa-Zastapila-BOR.pdf [access: 19.04.2018].

[17] Strona Secret Service, https://www.secretservice.gov/protection/\#who [access: 19.04.2018].

[18] ZAsкóRsкI, P., 2011. Zarządzanie organizacją w warunkach ryzyka utraty informacyjnej ciagłości działania, Warszawa.

[19] ZaskóRski, P., WoźNiak, J., SzWARC, K., Tomaszewski, Ł., 2015. Zarządzanie projektami w ujęciu systemowym. Wydanie drugie, Warszawa.

[20] Zieleniewski, J., 1978. Organizacja zespołów ludzkich. Wstęp do teorii organizacji i kierowania, Warszawa. 
